\title{
OPINIONS OF POLISH STUDENTS ON THE NEED FOR THE TRANSITION TO DISTANCE LEARNING WHEN FACING THE GLOBAL PANDEMIC COVID-19
}

\author{
Agnieszka PUTO \\ Technical University of Czestochowa; agnieszka.puto@pcz.pl, ORCID: 0000-0002-1947-0753
}

Purpose: The objective of the article is to present the condition of Polish universities and trends occurring in distance learning and e-learning. The results of the research conducted among students of Polish universities (N-2226), who were forced to the transition to distance learning from day to day, are presented in the article. Using well-known statistical measures, the correlations between the selected factors have been indicated. The research results on the correlations between the following variables have been presented - the opinions on the need for the transition to distance learning during the pandemic and:

- gender,

- age,

- taking up employment in addition to studying,

- an opportunity to study in a separate room.

Design/methodology/approach: For the research purposes, a well-known Internet Survey Panel was utilized, which was used to create and manage the surveys as well as to collect the results. The bivariate analysis was used, the objective of which was to determine the empirical relationship between the selected variables. In the research, among others, the following were used: Chi-Square Test for Independence, Phi-Square Test for Independence, Spearman's rank correlation test. For the data with the responses specified on the ordinal scale in the correlation analysis, Spearman's rank correlation coefficient was used.

Findings: The change in the teaching method which has been experienced in relation to the global pandemic may prove to be a breakthrough and give rise to changes in student education so as to educate the future staff of Industry 4.0 using distance learning. Increasing students' involvement in the learning process may help them acquire competences useful in their professional life more effectively.

Keywords: academic e-learning, distance learning, student, skills, stress, Industry 4.0.

Category of the paper: empirical. 


\section{Introduction}

On 2 March 2020 the Sejm of the Republic of Poland, passed a special law concerning specific solutions related to the prevention, counteraction and eradication of COVID-19, other infectious diseases and crisis situations caused by them. Originally, COVID-19 became the epidemic in Wuhan, China. Unfortunately, it spread rapidly and became an international issue (Anjorin, 2020; Burke, 2020; Phelan et al., 2020). Bill Gates called it the pandemic of the $21^{\text {st }}$ century (Gates, 2020). This unprecedented situation forced the governments of the countries to distance the society, including university students.

Higher education is facing a number of challenges nowadays, including quality, high costs, demographic decline, student diversity. On the threshold of the global pandemic associated with coronavirus disease COVID-19, Polish universities additionally have faced the need to modify their forms of education. The ban on physical contact have forced universities and students to move to work in the virtual environment, using distance learning, including e-learning.

The objective of the article is to present the condition of Polish universities and trends occurring in distance learning and e-learning. The results of the research conducted among students of Polish universities (N-2226), who were forced to the transition to distance learning from day to day, are presented in the article. Using well-known statistical measures, the correlations between the selected factors have been indicated. The research results on the correlations between the following variables have been presented - the opinions on the need for the transition to distance learning during the pandemic and:

- gender,

- age,

- taking up employment in addition to studying,

- an opportunity to study in a separate room.

It is worth pinpointing that the conducted research may become the contribution to further research in the context of Industry 4.0. Will the experience gained allow students for more effective development in the future professional life? Experiences associated with the sudden need for the transition to distance learning may enable an improvement in distance-learning courses and their adjustment to the needs of users. They are also a type of preparation to a remote form of education which is increasingly preferred by enterprises, particularly the ones aspiring to be Factories 4.0. 


\section{The condition of higher education in Poland at the end of 2018}

In Poland, there are 392 universities, including130 public ones and 262 non-public ones, including 15 run by religious organizations. As of 31 December 2018, there were 1230.3 thousand students at universities, i.e. by 61.6 thousand fewer compared to the previous year, including $73.3 \%$ at public universities. In the academic year of $2017 / 18$ the graduation diploma was awarded to 327.7 thousand graduates, i.e. by $15.4 \%$ less than in 2017 . The structure of students and graduates of Polish universities is presented in Figure 1.

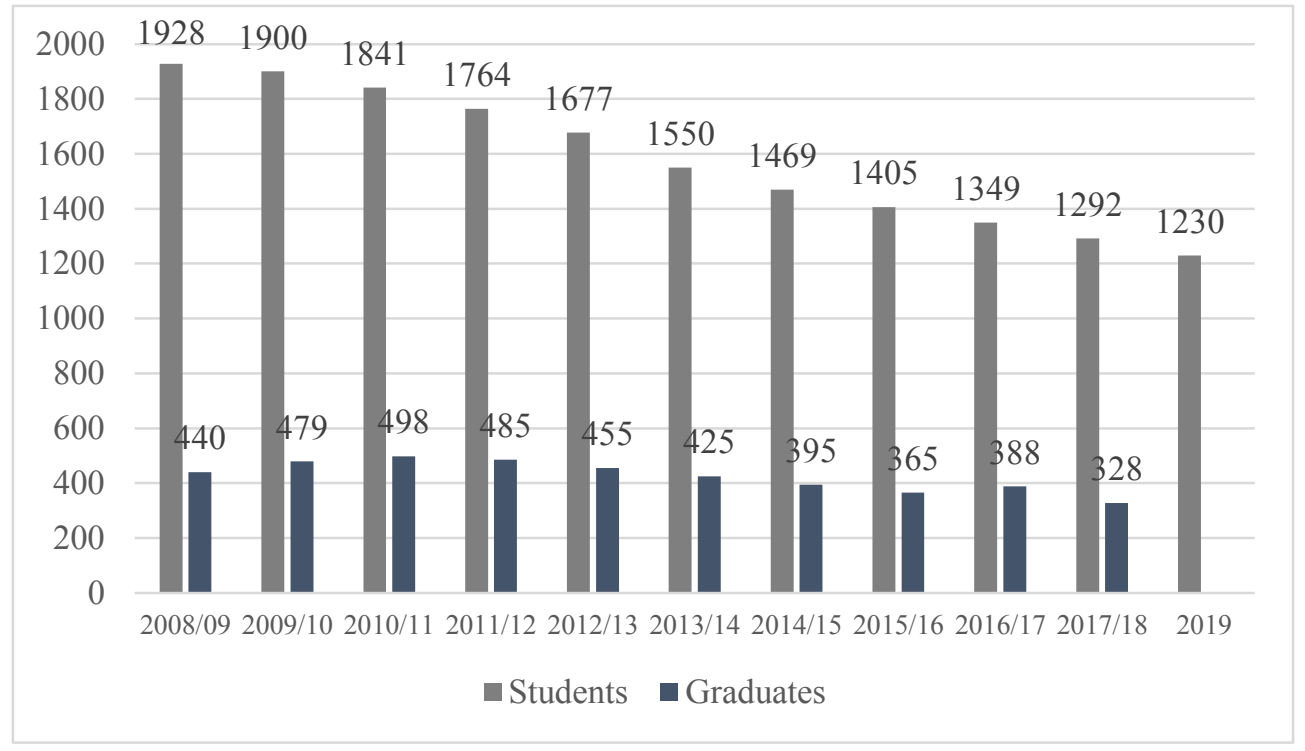

Figure 1. Students and graduates of universities in thousands (including foreigners). Central Statistical Office, 2019.

Over the last 10 years the number of students has decreased steadily, from 1927.8 thousand in the academic year of 2008/2009 to 1230.3 thousand in the academic year of 2018/2019. The largest number of graduates -497.5 thousand people - was recorded in the academic year of 2010/2011. Since then, the decrease in the number of graduates has been observed, to 327.7 thousand people in the academic year of 2017/2018. In the academic year of 2018/2019 women amounted to $58.0 \%$ of students. There were 809.3 thousand people registered for fulltime courses, i.e. $65.8 \%$ of students, whereas, 4210 thousand people for part-time courses. Nearly $64.0 \%$ of people (787.2 thousand) chose the first cycle degree programs. There were $24.1 \%$ of students in the second cycle degree programs, and $11.6 \%$ in the long-cycle Master's degree programs.

Table 1.

The number of students in Poland in 2018 in total

\begin{tabular}{|c|c|c|c|}
\hline Total & Including women & $\mathrm{A}$ & Foreigners out of the total number \\
\hline & Full-time & Part-time c & \\
\hline 1230254 & 713451 & 809259 & 420995 \\
\hline
\end{tabular}

Source: Central Statistical Office. 
Among the most frequently selected groups of courses, there were: Business, administration and law, where there were $22.0 \%$ of all the students, Technology, industry, construction (respectively 17.2\%), Social sciences, journalism and information and Health and social care (11.5\% each). 78.3 thousand foreigners, including 40.1 thousand women planned to study in Poland for at least one academic year, i.e. by $7.6 \%$ more than in the previous academic year. Most foreigners came from European countries, whereas the most numerous group was people from Ukraine (39.2 thousand, i.e. 50.1\% of all foreigners). The subsequent groups, in terms of the number, were students from Belarus (7.3 thousand - 9.3\%) and from India (3.6 thousand $4.6 \%)$. Full-time courses were taken up by 68.1 thousand foreigners $(87.0 \%)$.

\section{E-learning in Poland}

E-learning is becoming an increasingly popular form of educating students, increasing their qualifications and skills. The use of this method may considerably improve e-learning management, increase the quality of teaching individual subjects as well as the whole process of university education, reduce the costs of educating students, and also strengthen competitive advantage of the university in the education market (Jelonek, Dunay, Illes, p. 122). In a number of publications, technical and technological conditions of e-learning are pinpointed. Such a view is presented by the following definition: "e-learning is the use of electronic media for a variety of learning purposes that range from add-on functions in conventional classrooms to full substitution for the face-to-face meetings by online encounters" (Guri-Rosenblit, 2005).In Polish higher education, for several years, a trend has been observed associated with searching for new forms of using technology to support traditional academic teaching, which in turn would allow for an increase in students' involvement in the process of learning, which in turn would help them to acquire competences that are useful not only immediately after leaving the university but also in their professional life. E-learning provides opportunities which cannot be provided by traditional training. Some of the most important advantages of this form of education are primarily mobility, flexibility and interactivity. An opportunity to take part in the course, without leaving the desk, at any time convenient for oneself, is certainly an inestimable value. For employers, all of this also translates into a lower cost of implementation of this type of training. Therefore, there is no need to rent conference rooms, there is no need to arrive at the designated place and provide accommodation and board. An additional advantage of e-learning is the fact that the student or the employer is trained individually. Therefore, it depends on them how much time they will devote to training so as to complete it with a positive result. Thus, they are not dependent on the other participants of the course or the lecturer/trainer themselves. Materials and presentations can be browsed at any mobile devices at any time convenient for them. The presented material can be referred to at 
any time and the entire training can be repeated or its individual parts. This is definitely one of the main advantages of e-learning. Therefore, online education may provide educational space, allowing students to access educational opportunities, while continuing to fulfill their various work and family responsibilities (O'Shea, Stone, and Delahunty, 2015). E-learning relates to the whole of the processes associated with teaching and learning in the environment of and by means of modern information technologies, in particular the Internet. In terms of the educational approach, e-learning is a method of teaching, education supported by digital technologies. This aspect is also pinpointed by the following definition: "e-learning is the use of new multimedia technologies and the Internet to improve the quality of learning by facilitating access to resources and services, as well as remote exchange and collaboration" (Alonso et al., 2005).

Lederman (2020) rightly stated that, due to the COVID-19 crisis, teachers and students have found themselves in a situation in which they have felt compelled to adopt the digital academic experience as the summum bonum of the online teaching process. It is worth pinpointing that COVID-19 (EdSource, 2020) caused an enduring threat to our high school institutions and day by day exacerbated the teaching-learning.

\subsection{The results of own research on the opinion of Polish students in relation to the need for the transition to distance learning}

The research was conducted in the period of May-June 2020. It included a group of Polish students. The main objective of the research was to examine the opinion of Polish students on the need for the transition to distance learning during the pandemic of COVID-19. The survey questionnaire consisted of 36 questions, the questions using the Likert scale were used, both open and close-ended ones. The main objective of the research was to examine the mood of Polish students in relation to the need for the transition to distance learning. In the article, some of the survey research was presented. In the article, the results of the research into the correlations between the following variables were presented - the opinions on the need for the transition to distance learning and:

- gender,

- age,

- taking up employment in addition to studying,

- an opportunity to study in a separate room.

For the research purposes, a well-known Internet Survey Panel was utilized, which was used to create and manage the surveys as well as to collect the results. The bivariate analysis was used, the objective of which was to determine the empirical relationship between the selected variables. In the research, among others, the following were used: Chi-Square Test for Independence, Phi-Square Test for Independence, Spearman's rank correlation test. For the data with the responses specified on the ordinal scale in the correlation analysis, Spearman's rank correlation coefficient was used. Each time the value of the received coefficient was tested for 
its significance. Only statistically significant ones at the level of $\alpha=0.05$ were interpreted. For the data determined on the nominal scale in the correlation analysis, the $\chi 2$ measure and $\varphi-$ Youl's correlation coefficient were used. The value of the $\chi^{2}$ coefficient was tested for significance, and in the case of the data for which the number of cells was less than 5, Yates' correction was used.

\subsection{Characteristics of the surveyed respondents}

2226 students from Poland took part in the research. The questionnaire was sent to the university authorities, secretary's offices of individual scientific bodies, representatives of scientific circles. Most of the respondents who participated in the research were women (52\%). These were predominantly young people aged 21-25 (79\%). Most people were doing full-time $(82 \%)$ Master's courses (49\%). Nearly half of the people did not take up any gainful employment so far (41\% responded: "I do not work in addition to studying) - compare: Table 2.

Table 2.

The structure of the respondents $(N-2226)$

\begin{tabular}{|c|c|c|}
\hline Categories of the division & Specification & Percentage of the respondents \\
\hline \multirow{2}{*}{ Gender } & Female & $52 \%$ \\
\hline & Male & $48 \%$ \\
\hline \multirow{5}{*}{ Age } & Under 20 & $10 \%$ \\
\hline & $21-25$ & $79 \%$ \\
\hline & $26-30$ & $7 \%$ \\
\hline & $31-40$ & $3 \%$ \\
\hline & $41-50$ & $1 \%$ \\
\hline \multirow{2}{*}{ Type of studies } & Full-time & $82 \%$ \\
\hline & Part-time & $18 \%$ \\
\hline \multirow{3}{*}{ Degree of studies } & Bachelor's & $27 \%$ \\
\hline & Master's & $49 \%$ \\
\hline & Engineering & $24 \%$ \\
\hline \multirow{4}{*}{$\begin{array}{l}\text { Do you work in addition to } \\
\text { studying? }\end{array}$} & No & $41 \%$ \\
\hline & Yes, full-time & $34 \%$ \\
\hline & Yes, part-time & $1 \%$ \\
\hline & Yes, occasionally & $24 \%$ \\
\hline \multirow{2}{*}{$\begin{array}{l}\text { Do you have an opportunity to } \\
\text { study in a separate room? }\end{array}$} & Yes & $83 \%$ \\
\hline & No & $17 \%$ \\
\hline \multirow{3}{*}{$\begin{array}{l}\text { Do you have a connection that } \\
\text { allows you to learn via the Internet } \\
\text { without interruption? }\end{array}$} & Yes & $63 \%$ \\
\hline & No & $12 \%$ \\
\hline & Others & $25 \%$ \\
\hline \multirow{3}{*}{$\begin{array}{l}\text { Do you have the hardware and } \\
\text { software sufficient to learn via the } \\
\text { Internet without interruption? }\end{array}$} & Yes & $74 \%$ \\
\hline & No & $6 \%$ \\
\hline & Others & 20 \\
\hline
\end{tabular}

Source: The author's own research.

The condition of the Polish student's equipment is at a satisfactory level. $83 \%$ of the respondents had an opportunity to learn in a separate room, $63 \%$ of the respondents had a connection allowing them to learn via the Internet without interruption, and $74 \%$ of the respondents had the hardware and software sufficient for distance learning. Formulas should be 
aligned to the left. Each formula should have its number written in an Arabic numeral in parentheses (placed in line with the formula), aligned to the right edge of the page. For easier formatting, it is recommended to enter the formula in a table with invisible borders.

\subsection{The analysis of the research results}

The author of the research asked the students to express their opinions on a few aspects associated with distance learning. Nearly half (49\%) stated that they definitely had to deal with everything by themselves, which resulted in stress about the lack of time ( $44 \%$ - definitely yes) and the new situation (29\% - definitely yes). For a large part of the respondents, home conditions were not favorable ones (30\% - definitely yes), which was partially related to household chores (28\% - definitely yes) - compare Table 3.

Table 3.

The opinion of Polish students on the need for the transition to distance learning during the pandemic $(N-2226)$

\begin{tabular}{|l|c|c|c|c|c|}
\hline Specification & $\begin{array}{c}\text { I definitely } \\
\text { disagree }\end{array}$ & $\begin{array}{c}\text { I rather } \\
\text { disagree }\end{array}$ & $\begin{array}{c}\text { I have no } \\
\text { opinion }\end{array}$ & $\begin{array}{c}\text { I rather } \\
\text { agree }\end{array}$ & $\begin{array}{c}\text { I definitely } \\
\text { agree }\end{array}$ \\
\hline $\begin{array}{l}\text { I have an opportunity to acquire new } \\
\text { competences }\end{array}$ & $20 \%$ & $25 \%$ & $21 \%$ & $23 \%$ & $11 \%$ \\
\hline I'm getting to know new IT tools & $14 \%$ & $17 \%$ & $16 \%$ & $32 \%$ & $22 \%$ \\
\hline I'm learning time management & $20 \%$ & $20 \%$ & $17 \%$ & $25 \%$ & $19 \%$ \\
\hline $\begin{array}{l}\text { I'm learning to prioritize the tasks } \\
\text { entrusted, I first choose the most } \\
\text { important things to do and postpone the } \\
\text { less important ones }\end{array}$ & $14 \%$ & $14 \%$ & $15 \%$ & $31 \%$ & $26 \%$ \\
\hline I need to handle everything by myself & $5 \%$ & $10 \%$ & $11 \%$ & $26 \%$ & $49 \%$ \\
\hline I'm stressed about the lack of time & $11 \%$ & $12 \%$ & $13 \%$ & $20 \%$ & $44 \%$ \\
\hline $\begin{array}{l}\text { I do not have sufficient skills to handle } \\
\text { distance learning tools }\end{array}$ & $43 \%$ & $24 \%$ & $14 \%$ & $12 \%$ & $8 \%$ \\
\hline $\begin{array}{l}\text { I have a problem with the hardware } \\
\text { (a computer, a printer) }\end{array}$ & $37 \%$ & $22 \%$ & $13 \%$ & $17 \%$ & $11 \%$ \\
\hline I have no access to high-speed Internet & $36 \%$ & $18 \%$ & $14 \%$ & $17 \%$ & $15 \%$ \\
\hline I am stressed about the new situation & $21 \%$ & $13 \%$ & $15 \%$ & $22 \%$ & $29 \%$ \\
\hline $\begin{array}{l}\text { Family responsibilities make my } \\
\text { learning difficult }\end{array}$ & $18 \%$ & $16 \%$ & $15 \%$ & $23 \%$ & $28 \%$ \\
\hline $\begin{array}{l}\text { Home conditions are not favorable for } \\
\text { studying }\end{array}$ & $21 \%$ & $14 \%$ & $16 \%$ & $20 \%$ & $30 \%$ \\
\hline
\end{tabular}

Source: The author's own research.

In the first place, the hypothesis was formulated that the gender and age of students have an impact on the perception of factors associated with the need for the transition to distance learning during the pandemic (Table 4 and 5). 
Table 4.

The values of coefficients of the correlation between the responses on the need for the transition to distance learning during the pandemic and gender

\begin{tabular}{|c|c|c|c|}
\hline \multirow{2}{*}{ Response } & \multicolumn{3}{|c|}{ Coefficient } \\
\hline & Chi & Phi & p \\
\hline I have an opportunity to acquire new competences & 0.005 & 0.049 & 0.824 \\
\hline I'm getting to know new IT tools & -0.103 & 20.079 & 0.000 \\
\hline I'm learning time management & -0.078 & 11.267 & 0.001 \\
\hline $\begin{array}{l}\text { I'm learning to prioritize the tasks entrusted, I first choose the } \\
\text { most important things to do and postpone the less important ones }\end{array}$ & -0.033 & 2.043 & 0.153 \\
\hline I need to handle everything by myself & -0.071 & 9.895 & 0.002 \\
\hline I'm stressed about the lack of time & -0.067 & 8.534 & 0.003 \\
\hline I do not have sufficient skills to handle distance learning tools & -0.071 & 9.628 & 0.002 \\
\hline I have a problem with the hardware & -0.079 & 11.922 & 0.001 \\
\hline I have no access to high-speed Internet & -0.015 & 0.452 & 0.501 \\
\hline I'm stressed about the new situation & -0.130 & 32.052 & 0.000 \\
\hline Family responsibilities make my learning difficult & -0.011 & 0.223 & 0.636 \\
\hline Home conditions are not favorable for studying & -0.020 & 0.725 & 0.394 \\
\hline
\end{tabular}

Source: The author's own research.

As indicated by the statistical analyses carried out, there is no evidence of the statistically significant correlation between gender and an opportunity to acquire new competences in relation to the transition to distance learning during the pandemic.

\section{Table 5.}

The values of coefficients of the correlation between the responses on the need for the transition to distance learning during the pandemic and age

\begin{tabular}{|c|c|c|c|}
\hline \multirow{2}{*}{ Response } & \multicolumn{3}{|c|}{ Coefficient } \\
\hline & $\mathbf{R}$ & $\mathbf{t}(\mathbf{N}-2)$ & $\mathbf{p}$ \\
\hline I have an opportunity to acquire new competences & 0.009 & 0.433 & 0.665 \\
\hline I'm getting to know new IT tools & -0.029 & -1.385 & 0.166 \\
\hline I'm learning time management & -0.003 & -0.120 & 0.904 \\
\hline $\begin{array}{l}\text { I'm learning to prioritize the tasks entrusted, I first choose the } \\
\text { most important things to do and postpone the less important ones }\end{array}$ & -0.018 & -0.862 & 0.389 \\
\hline I need to handle everything by myself & -0.033 & -1.539 & 0.124 \\
\hline I'm stressed about the lack of time & -0.083 & -3.938 & 0.000 \\
\hline I do not have sufficient skills to handle distance learning tools & -0.089 & -4.226 & 0.000 \\
\hline I have a problem with the hardware & -0.064 & -3.027 & 0.002 \\
\hline I have no access to high-speed Internet & -0.073 & -3.429 & 0.001 \\
\hline I'm stressed about the new situation & -0.097 & -4.574 & 0.000 \\
\hline Family responsibilities make my learning difficult & 0.019 & 0.913 & 0.361 \\
\hline Home conditions are not favorable for studying & -0.002 & -0.104 & 0.917 \\
\hline
\end{tabular}

Source: The author's own research.

The results of the statistical research did not confirm the existence of the statistically significant correlation between age and an opportunity to acquire new competences in relation to the transition to distance learning during the pandemic. Subsequently, it was examined whether the entrepreneurship of students manifesting itself in taking up employment in the course of studies was favorable for handling the new situation (Table 6). 
Table 6.

The values of coefficients of the correlation between the responses on the need for the transition to distance learning during the pandemic and taking up employment in addition to studying

\begin{tabular}{|l|l|l|l|}
\hline \multicolumn{1}{|c|}{ Response } & \multicolumn{2}{c|}{ Coefficient } \\
\cline { 2 - 4 } & \multicolumn{1}{|c|}{$\mathbf{R}$} & \multicolumn{1}{c|}{ t(N-2) } & \multicolumn{1}{c|}{ p } \\
\hline I have an opportunity to acquire new competences & -0.077 & -3.631 & 0.000 \\
\hline I'm getting to know new IT tools & -0.097 & -4.580 & 0.000 \\
\hline I'm learning time management & -0.044 & -2.054 & 0.040 \\
\hline $\begin{array}{l}\text { I'm learning to prioritize the tasks entrusted, I first choose the } \\
\text { most important things to do and postpone the less important ones }\end{array}$ & -0.062 & -2.924 & 0.003 \\
\hline I need to handle everything by myself & 0.054 & 2.567 & 0.010 \\
\hline I'm stressed about the lack of time & -0.028 & -1.319 & 0.187 \\
\hline I do not have sufficient skills to handle distance learning tools & 0.030 & 1.403 & 0.161 \\
\hline I have a problem with the hardware & 0.019 & 0.876 & 0.381 \\
\hline I have no access to high-speed Internet & -0.031 & -1.469 & 0.142 \\
\hline I'm stressed about the new situation & -0.079 & -3.756 & 0.000 \\
\hline Family responsibilities make my learning difficult & 0.109 & 5.179 & 0.000 \\
\hline Home conditions are not favorable for studying & 0.063 & 2.966 & 0.003 \\
\hline
\end{tabular}

Source: The author's own research.

There is a statistically significant negative correlation between taking up employment in addition to studying and learning time management, at the level of -0.44 . The people employed indicate learning time management more rarely - they must have acquired these skills earlier in connection with the fulfillment of different tasks simultaneously. Another hypothesis related to home conditions in which students were to study. It was assumed that students with an opportunity to study in a separate room more favorably accept the new situation related to the need for studying at home (Table 7).

Table 7.

The values of coefficients of the correlation between the responses on the need for the transition to distance learning during the pandemic and an opportunity to study in a separate room

\begin{tabular}{|c|c|c|c|}
\hline \multirow{2}{*}{ Response } & \multicolumn{3}{|c|}{ Coefficient } \\
\hline & Chi & Phi & p \\
\hline I have an opportunity to acquire new competences & -0.087 & 13.381 & 0.000 \\
\hline I'm getting to know new IT tools & -0.126 & 29.967 & 0.000 \\
\hline I'm learning time management & -0.094 & 16.181 & 0.000 \\
\hline $\begin{array}{l}\text { I'm learning to prioritize the tasks entrusted, I first choose the } \\
\text { most important things to do and postpone the less important ones }\end{array}$ & -0.096 & 17.626 & 0.000 \\
\hline I need to handle everything by myself & 0.026 & 1.379 & 0.240 \\
\hline I'm stressed about the lack of time & 0.079 & 11.993 & 0.001 \\
\hline I do not have sufficient skills to handle distance learning tools & 0.090 & 15.386 & 0.000 \\
\hline I have a problem with the hardware & 0.155 & 46.755 & 0.000 \\
\hline I have no access to high-speed Internet & 0.117 & 26.451 & 0.000 \\
\hline I'm stressed about the new situation & 0.094 & 16.793 & 0.000 \\
\hline Family responsibilities make my learning difficult & 0.170 & 54.777 & 0.000 \\
\hline Home conditions are not favorable for learning & 0.194 & 70.245 & 0.000 \\
\hline
\end{tabular}

Source: The author's own research.

The results of the statistical analysis indicated that there is a statistically significant positive correlation between being stressed about the new situation and an opportunity to study in a separate room at the level of 0.094 . People not having a separate room assess the level of stress resulting from the new situation significantly higher. 


\section{Conclusion}

The results of the research indicate that gender and age are not significant in terms of the approach to distance learning. Home conditions in which the students study and entrepreneurial actions they have taken so far turn out to be significant. Not having a separate room to study results in higher stress related to studying. In turn, people combining professional work with studying handle time management better. Undoubtedly, distance learning is a modern form of education which is inscribed in the Industry 4.0 methods of educating staff. The concept assumes that in 10-15 years a significant part of industrial production will be carried out by smart digitized factories in which the product and process mechatronization will dominate, achieved due to saturation with automation devices, robotic production lines, remote control systems - carried out using IT and Internet tools (Saniuk, Saniuk, 2017, pp. 12-15). Changes in production processes will only be possible if adequate human capital is guaranteed. New areas, still not defined today, will require new competences and new specialists. The pace of changes may be high, therefore, the changes to the profession, subsequent retraining, the need for constant further training will be necessary. All of this causes that distance learning, which has been experienced globally, plays the key role in preparing students to act in the face of the upcoming fourth industrial revolution. In Industry 4.0, a natural thing will be to include the activities directed to training in staff development programs, using the resources stored on computers and activities performed in the network. This results from the fact that ICT significantly enables the transfer of knowledge, not only by more effective exchange of data but, most of all, due to unique methods for their presentation. Therefore, the change in the teaching method which has been experienced in relation to the global pandemic may prove to be a breakthrough and give rise to changes in student education so as to educate the future staff of Industry 4.0 using distance learning. Increasing students' involvement in the learning process may help them acquire competences useful in their professional life more effectively. You can also use abbreviated notation, when in the paper we already mention a given author, report or legal act, e.g. Smith (2017).

\section{References}

1. Alonso, F., López, G., Manrique, D., Viñes, J.M. (2005). An instructional model for webbased e-learning education with a blended learning process approach. British Journal of Educational Technology, 36(2).

2. Anjorin, A.A. (2020). The coronavirus disease 2019 (COVID-19) pandemic: A review and an update on cases in Africa. Asian Pacific Journal of Tropical Medicine, 13(5), p. 199. 
3. Burke, R.M. (2020). Active monitoring of persons exposed to patients with confirmed COVID-19-United States, January-February 2020. MMWR. Morbidity and Mortality Weekly Report, 69(9), pp. 245-246.

4. Central Statistical Office (2019). Szkolnictwo wyższe w roku akademickim 2018/2019, https://stat.gov.pl/obszary-tematyczne/edukacja/edukacja/szkolnictwo-wyzsze-w-rokuakademickim-20182019-wyniki-wstepne,8,6.html, 01.09.2020.

5. EdSource (2020). Coronavirus: Highlighting strategies for student success. Retrieved from https://edsource.org/topic/coronavirus.

6. Eze, S.C., Chinedu-Eze, V. C., \& Bello, A.O. (2018). The utilisation of e-learning facilities in the educational delivery system of Nigeria: a study of M-University. International Journal of Educational Technology in Higher Education, 15(1), p. 34.

7. Grabara, J. (2013). Sustainable Logistics Management. Sibiu Editura Universitatii "Lucian Blaga" din Sibiu.

8. Gates, B. (2020). Responding to Covid-19-a once-in-a-century pandemic? New England Journal of Medicine, 382(18), pp. 1677-1679.

9. Guri-Rosenblit, S. (2005). Distance education and e-learning: Not the same thing. Higher Education, 49(4).

10. Jelonek, D., Dunay, A., Illes, B.C. (2017). Academic e-learning management with e-learning scorecard. Polish Journal Of Management Studies, 16(2), p. 122.

11. Lederman, D. (2020). Will shift to remote teaching be boon or bane for inline learning? Inside Higher Ed., March 18.

12. O'Shea, Stone, and Delahunty (2015). I 'feel' like I am at university even though I am online. Exploring how students narrate their engagement with higher education institutions in an online learning environment. Distance Education, 36. DOI: 10.1080/ 01587919.2015.1019970.

13. Phelan, A.L., Katz R., \& Gostin L.O. (2020). The novel coronavirus originating in Wuhan, China: challenges for global health governance. Jama, 323(8), pp. 709-710.

14. Saniuk, S., Saniuk, A. (2017). Analiza sytuacji polskich przedsiębiorstw w sieciach przemysłowych w dobie Industry 4.0. Management Sciences, Nauki o Zarządzaniu, 2(31), Wrocław: Uniwersytet Ekonomiczny, pp. 12-15.

15. Zheng, Y., Ma, Y., Zhang, J. et al. (2020). COVID-19 and the cardiovascular system. Nat. Rev. Cardiol., 17, 259-260, DOI: 10.1038/s41569-020-0360-5. 